\title{
The Speed Electromagnetic Wave Propagation in the Snow-Ice Underlying Surface
}

\author{
Vladimir A. Malyshev and Viktor G. Mashkov* \\ Military Education and Research Centre of Military-Air Forces \\ «Military-Air Academy \\ Named After Professor N.E. Zhukovsky and Yu.A. Gagarin» \\ Voronezh, Russian Federation
}

Received 19.02.2021, received in revised form 16.03.2021, accepted 21.04.2021

\begin{abstract}
The results calculations the electromagnetic wave propagation velocity in the snow-ice cover depending on the density, the proportion liquid water content, and the propagation speeds the electromagnetic wave in dry snow, dry firn, and dry ice vary very markedly depending on the proportion liquid water content, the preferred orientation, and the shape ice and air structure are presented. The inclusions in the snow.

The performed estimates the complex relative permittivity the medium that determines the speed propagation electromagnetic waves show a noticeable influence the density, the proportion liquid water content and the structure the underlying surface (snow, firn, ice), which allows identifying the layers the underlying surface in order to remotely determine the possibility landing a helicopter-type aircraft on an unprepared site with snow-ice cover.

Shown, when the portion the water content in the medium is equal to zero, which is typical for negative temperatures, the speed propagation electromagnetic waves in the medium will depend on the density the medium and structure the dry ice in a small range of $1 \mathrm{~m} / \mu$ s temperature. In dry snow, vertically and horizontally elongated or spherical inclusions make a significant contribution to the change in the speed propagation the electromagnetic wave. At zero temperature, in the frequency range of $2 \ldots 8 \mathrm{GHz}$, the share water content in the medium, the density and structure the medium will play a determining role in the speed propagation an electromagnetic wave in the medium.

The purpose this article is to determine the change ranges speed propagation electromagnetic waves in snow-ice the underlying surface depending on the density, structure, water content to restore the structure the snow and ice according to radar sensing, a more accurate determination the depth snow and thickness ice cover used in the assessment the possibility the safe landing an aircraft the helicopter type on an unprepared ground with snow-ice cover.
\end{abstract}

Keywords: snow cover, ice cover, underlying surface, dielectric permittivity, electromagnetic wave propagation speed.

Citation: Malyshev V.A., Mashkov V.G. The speed electromagnetic wave propagation in the snow-ice underlying surface, J. Sib. Fed. Univ. Eng. \& Technol., 2021, 14(3), 332-346. DOI: 10.17516/1999-494X-0313

(C) Siberian Federal University. All rights reserved

This work is licensed under a Creative Commons Attribution-Non Commercial 4.0 International License (CC BY-NC 4.0).

* Corresponding author E-mail address: mvgblaze@mail.ru 


\title{
Скорость распространения электромагнитной волны
}

\section{В снежно-ледяной подстилающей поверхности}

\author{
В. А. Малышев, В. Г. Машков \\ Военный учебно-научный цеентр ВВС \\ «Военно-воздушная академия \\ имени профессора Н.Е. Жуковского и Ю. А. Гагарина» \\ Российская Федерациия, Воронеж
}

\begin{abstract}
Аннотация. Представлены результаты расчетов скорости распространения электромагнитной волны в снежно-ледяном покрове в зависимости от плотности, доли содержания воды и структуры. Скорости распространения электромагнитной волны в сухом снеге, сухом фирне и сухом льде весьма заметно изменяются в зависимости от доли содержания воды, преимущественной ориентировки и формы включений льда и воздуха в снеге.

Выполненные оценки комплексной относительной диэлектрической проницаемости среды, определяющей скорость распространения электромагнитных волн, показывают заметное влияние плотности, доли содержания воды и структуры подстилающей поверхности (снег, фирн, лед), что позволяет идентифицировать слои подстилающей поверхности с целью дистанционного определения возможности посадки воздушного судна вертолетного типа на неподготовленную площадку со снежно-ледяным покровом.

При доле содержания воды в среде, равной нулю, что характерно для отрицательных температур, скорость распространения электромагнитной волны в среде будет зависеть только от плотности среды и ее структуры, для сухого льда в незначительных пределах 1 м/мкс от температуры. В сухом снеге весомый вклад в изменение скорости распространения электромагнитной волны вносят вертикально и горизонтально вытянутые либо сферические включения. При нулевой температуре в диапазоне частот $2 \ldots 8$ ГГц определяющую роль в скорости распространения электромагнитной волны в среде будет играть доля содержания воды в среде, плотность и структура среды.

Цель данной статьи - определить диапазоны изменения скорости распространения электромагнитной волны в снежно-ледяной подстилающей поверхности в зависимости от плотности, структуры, содержания воды для восстановления структуры снежно-ледяного покрова по данным радиолокационного зондирования, более точного определения глубины снежного и толщины ледяного покрова, используемых в оценке возможности выполнения безопасной посадки воздушного судна вертолетного типа на неподготовленную площадку со снежно-ледяным покровом.
\end{abstract}

Ключевые слова: снежный покров, ледяной покров, подстилающая поверхность, диэлектрическая проницаемость, скорость распространения электромагнитной волны.

Цитирование: Малышев, В.А. Скорость распространения электромагнитной волны в снежно-ледяной подстилающей поверхности / В.А. Малышев, В.Г. Машков // Журн. Сиб. федер. ун-та. Техника и технологии, 2021, 14(3). С. $332-346$. DOI: $10.17516 / 1999-494 X-0313$

\section{Introduction}

The accuracy measuring the depth snow and the thickness the ice cover when landing a helicoptertype aircraft (HTA) on an unprepared snow-ice platform directly affects the level flight safety. Landing on a snow-covered reservoir with a depth snow cover above the permissible or with a thickness ice cover below the permissible can lead to sinking under snow, ice, or to overturning the HTA day and night, in simple and complex weather conditions (fog, haze, rain, snow, dust or smoke in the atmosphere), as 
well as in conditions raised snow by its rotating screw [1]. The need for such a landing may be caused, for example, by cargo delivery, search and rescue operations, or evacuation of the wounded.

When measuring the depth snow and the thickness ice cover by radar, its accuracy will depend on the accuracy measuring the time delay and the speed propagation an electromagnetic wave (EW) in a medium other than the speed propagation EW in a vacuum $c=2,99792458 \cdot 10^{8} \mathrm{~m} / \mathrm{s}$, depending on its dielectric constant. A snow-ice surface is a three-component medium that is a mixture ice with water and air inclusions [2]. In turn, the dielectric permittivity the snow-ice underlying surface, depending on the density and proportion water content, will vary significantly. Since, for example, the real part the static permittivity melt water is $\varepsilon_{\text {mw s }}^{\prime}=87,9[2,3]$, and dry dense ice (without air inclusions) $\varepsilon_{\mathrm{di}}^{\prime}=3,20 \pm 0,02[2-5]$.

The value the permittivity dry snow cover is between ice and air $\varepsilon_{\mathrm{a}}^{\prime}=1$ depending on the density, as well as the preferred orientation and form inclusions ice and air in the snow. Depending on the shape the crystals, snow may have different physical properties. The snow density varies for open areas, forests, and melting snow and is in a very wide range of $10 . .700 \mathrm{~kg} / \mathrm{m}^{3}$, which affects all snow characteristics.

Denser, solidified granular and partially recrystallized, usually long-term snow (firn), or rather the intermediate stage between snow and glacier ice has a density of $450 \ldots 800 \mathrm{~kg} / \mathrm{m}^{3}$ due to interconnected ice grains [6].

Since the density snow on the height the snow cover is very heterogeneous and is determined by the depth and duration its occurrence, the density snow cover is an average value.

In the European part of Russia, the average density snow cover at the end the winter period in the Northern regions is within $220 \ldots 280 \mathrm{~kg} / \mathrm{m}^{3}$, in the middle zone $-240 \ldots 320 \mathrm{~kg} / \mathrm{m}^{3}$, in the South $220 \ldots 360 \mathrm{~kg} / \mathrm{m}^{3}$, the wider limits are explained by intermittent thaws. The presence water and water vapor (moisture) significantly increases the density snow cover. Melting snow has a higher density value, so in most cases at the beginning melting it is within the range $180 \ldots 350 \mathrm{~kg} / \mathrm{m}^{3}$, changes at the height melting to $350 \ldots 450 \mathrm{~kg} / \mathrm{m}^{3}$, at the end melting it reaches $600 \mathrm{~kg} / \mathrm{m}^{3}$ [6].

\section{Property water}

The static permittivity water is great importance, which is explained by the chemical structure the $\mathrm{H}_{2} \mathrm{O}$ molecule. The orientation degree freedom molecular dipoles and their rotation largely determine the electrical properties water [7]. Dipoles are randomly oriented in the absence an external electric field $(\mathrm{EF})$, and the total EF they create is zero. The action the EF contributes to the reorientation the dipoles, leading to its weakening. In all polar liquids, this happens, but water is able to weaken the external field by almost 80 times. With increasing frequency, the dipoles do not keep up with the external EF and stop reacting to it, while the value the water's permittivity decreases to $4 . . .5$ for frequencies greater than $10^{12} \mathrm{~Hz}$. In this case, the permittivity is determined only by the atomicmolecular redistribution the electric charge characteristic all substances.

According to $[7,8]$, the complex relative permittivity pure water $\varepsilon_{\text {pw }}$ (Fig. 1a) depends on the frequency $f(\mathrm{GHz})$ and temperature $T_{\mathrm{pw}}\left({ }^{\circ} \mathrm{C}\right), \varepsilon_{\mathrm{pw}}$ defined by the formula (1), real part $\varepsilon_{\mathrm{pw}}^{\prime}-(2)$, imaginary part $\varepsilon_{\mathrm{pw}}^{\prime \prime}-(3)$ :

$$
\varepsilon_{\mathrm{pw}}=\varepsilon_{\mathrm{pw}}^{\prime}-j \varepsilon_{\mathrm{pw}}^{\prime \prime}
$$




$$
\begin{aligned}
& \varepsilon_{\mathrm{pw}}^{\prime}=\frac{\varepsilon_{\mathrm{pws}}-\varepsilon_{\mathrm{pw} 1}}{1+\left(f / f_{\mathrm{pwr} 1}\right)^{2}}+\frac{\varepsilon_{\mathrm{pw} 1}-\varepsilon_{\mathrm{pw} \infty}}{1+\left(f / f_{\mathrm{pw} 2}\right)^{2}}+\varepsilon_{\mathrm{pw} \infty} ; \\
& \varepsilon_{\mathrm{pw}}^{\prime \prime}=\frac{\left(f / f_{\mathrm{pwr} 1}\right)\left(\varepsilon_{\mathrm{pw}}-\varepsilon_{\mathrm{pw} 1}\right)}{1+\left(f / f_{\mathrm{pwr} 1}\right)^{2}}+\frac{\left(f / f_{\mathrm{pw} 2}\right)\left(\varepsilon_{\mathrm{pw} 1}-\varepsilon_{\mathrm{pw} \infty}\right)}{1+\left(f / f_{\mathrm{pw} \mathrm{r} 2}\right)^{2}},
\end{aligned}
$$

where: $\varepsilon_{\mathrm{pws}}, \varepsilon_{\mathrm{pwl}}=0,0671 \varepsilon_{\mathrm{pws}}, \varepsilon_{\mathrm{pw} \infty}-$ static, current, and dynamic permittivity pure water, respectively; $f_{\mathrm{pw} \mathrm{rl}}$ and $f_{\mathrm{pw} \mathrm{r} 2}=39,8 f_{\mathrm{pw} \mathrm{r} 1}-$ Debye relaxation frequencies.

Since water is a good solvent, in nature certain salts are almost always dissolved in it, that is, there are positive and negative ions in the water. Water is weakly dissociated under normal conditions and the concentration of protons (hydroxonium $\mathrm{H}_{3} \mathrm{O}^{+}$ions) and hydroxyl $\mathrm{OH}^{-}$ions is $0,1 \mu \mathrm{mol} / 1$ [9]. Electrical conductivity, as a numerical expression the ability an aqueous solution to conduct an electric current natural water, is determined mainly by the concentration dissolved mineral salts and temperature. Natural waters are mainly solutions mixtures strong electrolytes, the mineral part which is made up ions $\mathrm{Na}^{+}, \mathrm{K}^{+}, \mathrm{Ca}^{2+}, \mathrm{Cl}^{-}, \mathrm{SO}_{4}{ }^{2-}, \mathrm{HCO}_{3}{ }^{-}$, which determines the electrical conductivity. Other ions, for example, $\mathrm{Fe}^{3+}, \mathrm{Fe}^{2+}, \mathrm{Mn}^{2+}, \mathrm{Al}^{3+}, \mathrm{NO}_{3}{ }^{-}, \mathrm{HPO}_{4}{ }^{-}, \mathrm{H}_{2} \mathrm{PO}_{4}^{-}$ they do not significantly affect the electrical conductivity if they are contained in water in small fractions.

The normalized values mineralization approximately corresponds to the specific electrical conductivity $2 \mu \mathrm{Sm} / \mathrm{cm}\left(\mathrm{Sm}\right.$ - Siemens, the inverse Ohm) $\left(1000 \mathrm{mg} / \mathrm{dm}^{3}\right)$ и $3 \mu \mathrm{Sm} / \mathrm{cm}\left(1500 \mathrm{mg} / \mathrm{dm}^{3}\right)$ for chloride (in terms of $\mathrm{NaCl}$ ) and carbonate (in terms of $\mathrm{CaCO}_{3}$ ) mineralization [9]. The specific electrical conductivity water characterizes the salinity fresh water (salinity seawater) depending on the temperature, concentration and nature ions, for distilled water $T_{\mathrm{pw}}=25{ }^{\circ} \mathrm{C}$ respond $2 . .5 \mu \mathrm{Sm} / \mathrm{cm}$, precipitation $-6 \ldots 30 \mu \mathrm{Sm} / \mathrm{cm}$ and more, in highly polluted air mediums, river and fresh lake waters $20 \ldots 80 \mu \mathrm{Sm} / \mathrm{cm}$.

The salinity sea water varies within: for the Baltic sea $S_{\mathrm{pw}}=10 \ldots 12 \mathrm{~g} / \mathrm{kg}$ (Gulf of Finland $S_{\mathrm{sw}}=2 \ldots 3 \mathrm{~g} / \mathrm{kg}$, in the Danish Straits $S_{\mathrm{sw}}=20 \mathrm{~g} / \mathrm{kg}$ at the surface the sea and $S_{\mathrm{pw}}=30 \mathrm{~g} / \mathrm{kg}$ near the bottom); for the red sea $S_{\mathrm{sw}}=40 \ldots 42 \mathrm{~g} / \mathrm{kg}$; for the Dead sea $S_{\mathrm{sw}}=300 \ldots 310 \mathrm{~g} / \mathrm{kg}$ (before $S_{\mathrm{sw}}=350 \mathrm{~g} / \mathrm{kg}$ ). Salinity the world ocean water $S_{\mathrm{sw}}=30 \mathrm{~g} / \mathrm{kg}$.

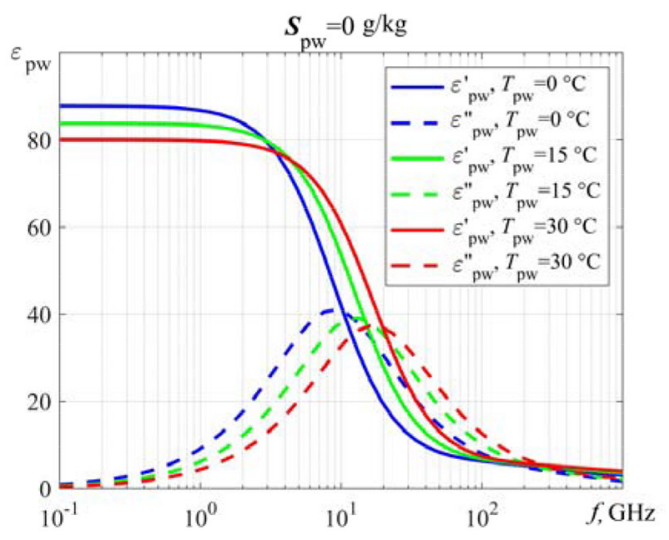

a)

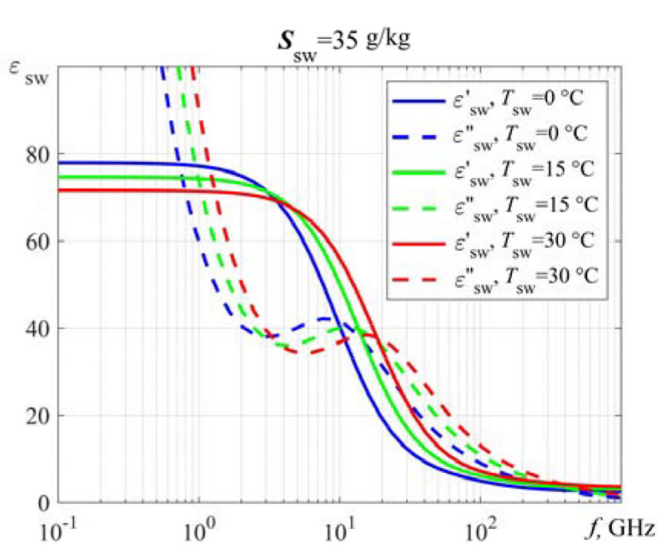

b)

Fig. 1. Dependence the complex relative permittivity: a $-\varepsilon_{\mathrm{pw}}$ pure water $S_{\mathrm{pw}}=0 \mathrm{~g} / \mathrm{kg}$ by $(1-3) ; \mathrm{b}-\varepsilon_{\mathrm{sw}}$ sea water $S_{\text {sw }}=35 \mathrm{~g} / \mathrm{kg}$ by (4-6), from frequency $f$ at $T_{\mathrm{r}}=0 ; 15 ; 30^{\circ} \mathrm{C}$ 
According to [8], the complex relative permittivity seawater $\varepsilon_{\mathrm{sw}}$ (Fig. 1b) depends on the frequency $f(\mathrm{GHz})$, temperatures $T_{\mathrm{sw}}\left({ }^{\circ} \mathrm{C}\right)$ and salinity $S_{\mathrm{sw}}\left(\mathrm{g} / \mathrm{kg}\right.$ or ppt), $\varepsilon_{\mathrm{sw}}$ defined by the formula (4), the real part $\varepsilon_{\mathrm{sw}}^{\prime}-(5)$, imaginary part $\varepsilon_{\mathrm{sw}}^{\prime \prime}-(6)$ :

$$
\begin{aligned}
& \varepsilon_{\mathrm{sw}}=\varepsilon_{\mathrm{sw}}^{\prime}-j \varepsilon_{\mathrm{sw}}^{\prime \prime} ; \\
& \varepsilon_{\mathrm{sw}}^{\prime}=\frac{\varepsilon_{\mathrm{sws}}-\varepsilon_{\mathrm{sw} 1}}{1+\left(f / f_{\mathrm{swr}}\right)^{2}}+\frac{\varepsilon_{\mathrm{sw} 1}-\varepsilon_{\mathrm{sw} \infty}}{1+\left(f / f_{\mathrm{sw} 2}\right)^{2}}+\varepsilon_{\mathrm{sw} \infty} ; \\
& \varepsilon_{\mathrm{sw}}^{\prime \prime}=\frac{\left(f / f_{\mathrm{swr} 1}\right)\left(\varepsilon_{\mathrm{sw}}-\varepsilon_{\mathrm{sw1} 1}\right)}{1+\left(f / f_{\mathrm{swr}}\right)^{2}}+\frac{\left(f / f_{\mathrm{sw} 2}\right)\left(\varepsilon_{\mathrm{sw1}}-\varepsilon_{\mathrm{sw} \infty}\right)}{1+\left(f / f_{\mathrm{sw} 2}\right)^{2}}+\frac{18 \sigma_{\mathrm{sw} \infty}}{f},
\end{aligned}
$$

where $\sigma_{\mathrm{sw} \text { s }}$ - the conductivity seawater is dependent on salinity sea water $S_{\mathrm{sw}}$ and temperature $T_{\mathrm{sw}}$. By $S_{\mathrm{sw}}=35 \mathrm{~g} / \mathrm{kg}$ and $T_{\mathrm{sw}}=0{ }^{\circ} \mathrm{C} \sigma_{\mathrm{sw} \mathrm{s}}=2,9036$.

As can be seen from Fig. 1 the value the complex relative permittivity water with increasing salinity $S_{\mathrm{sw}}$ and temperature $T$ decreases. It should be noted that the water density reaches its maximum values $999,972 \mathrm{~kg} / \mathrm{m}^{3}$ at temperature $T=3,8 \ldots 4,2{ }^{\circ} \mathrm{C}[10]$, as the temperature decreases further, the density decreases. This temperature dependence density is typical only for water.

\section{Properties the ice sheet}

The electrical conductivity ice and snow is many times less than that water. The presence various impurities in water has a significant effect on its electrical conductivity and practically does not affect the electrical conductivity ice. Partial dissociation molecules into $\mathrm{H}^{+}$and $\mathrm{OH}$-ions determines the electrical conductivity chemically pure water. Movements of $\mathrm{H}^{+}$ions (proton jumps), which create two types defects in the ice structure: ionic and orientation, have a major influence on the electrical conductivity water and ice. In the first case, the proton jumps along the hydrogen bond from one $\mathrm{H}_{2} \mathrm{O}$ molecule to another, resulting in a pair ion defects $\mathrm{H}_{3} \mathrm{O}^{+}$and $\mathrm{OH}^{-}$, and in the second to the neighboring hydrogen bond in one $\mathrm{H}_{2} \mathrm{O}$ molecule, while a pair orientation $\mathrm{L}$ and D-defects occurs [9, 11].

As the temperature increases, the electrical conductivity increases exponentially, which distinguishes ice from metal conductors and puts it on a par with semiconductors. Ice is usually very clean chemically, even if it has grown from contaminated water or solution, because it has a low solubility impurity in the structure. When freezing at the crystallization front, the impurities are pushed into the liquid, do not enter the structure ice, so the newly fallen snow is white, and the water from it is exceptionally clean. Ice is a proton semiconductor, since the charge carriers are disordered protons and there are no free electrons in it, as in metals $[9,11]$.

According to [8] the complex relative permittivity dry ice $\varepsilon_{\mathrm{di}}$ consisting frozen water, i.e. $T \leq 0{ }^{\circ} \mathrm{C}$

$$
\varepsilon_{\mathrm{di}}=\varepsilon_{\mathrm{di}}^{\prime}-j \varepsilon_{\mathrm{di}}^{\prime \prime}
$$

The real part the complex relative permittivity $\varepsilon_{\mathrm{di}}^{\prime}$ depend on temperature $T_{\mathrm{di}}$ and it doesn't depend on the frequency $f$. For dense ice when $T_{\mathrm{di}}=0{ }^{\circ} \mathrm{C} \varepsilon_{\mathrm{di}}^{\prime}=3,19 \pm 0,04[12,13]$, a in the temperature range $T_{\mathrm{di}}=0 \ldots-20^{\circ} \mathrm{C}$, characteristic Subpolar and warm glaciers, this dependence is described by the equation $\varepsilon_{\mathrm{di}}^{\prime}=3,1968 \pm 0,061 T_{\mathrm{di}}[12,13]$, according to [8]

$$
\varepsilon_{\mathrm{di}}^{\prime}=3,1884+0,00091 T_{\mathrm{di}}
$$


an imaginary part the complex relative permittivity $\varepsilon_{\mathrm{di}}^{\prime \prime}$ depend on temperature $T_{\mathrm{di}}$ and the frequency $f[8]$ :

$$
\varepsilon_{\mathrm{di}}^{\prime \prime}=\frac{A}{f}+B f
$$

where:

$$
\begin{aligned}
& A=\left(0,00504+0,0062\left(\frac{300}{T_{\mathrm{di}}+273,15}-1\right)\right) \exp \left(-22,1\left(\frac{300}{T_{\mathrm{di}}+273,15}-1\right)\right) \\
& B=\frac{0,0207}{T_{\mathrm{di}}+273,15} \frac{\exp \left(-\frac{335}{T_{\mathrm{di}}+273,15}\right)}{\left(\exp \left(-\frac{335}{T_{\mathrm{di}}+273,15}\right)-1\right)^{2}}+1,16 \times 10^{-11} f^{2}+\exp \left(-9,963+0,0372 T_{\mathrm{di}}\right) .
\end{aligned}
$$

Real $\varepsilon_{\mathrm{di}}^{\prime}(8)$ and the imaginary $\varepsilon_{\mathrm{di}}^{\prime \prime}$ (9) parts the complex relative permittivity dry ice are shown in the Fig. 2 [8] for $T_{\mathrm{di}}=-20^{\circ} \mathrm{C}$ from frequency $f$.

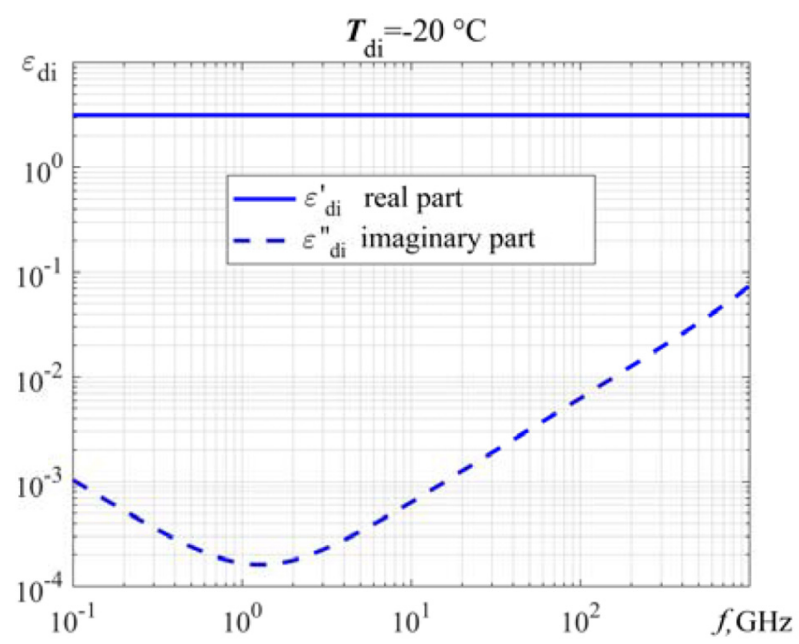

Fig. 2. Dependence the complex relative permittivity dry ice $\varepsilon_{\mathrm{di}}$ by (7-9) from frequency $f$ at $T_{\mathrm{di}}=-20^{\circ} \mathrm{C}$

When the ice is wet $T_{\mathrm{wi}}=0{ }^{\circ} \mathrm{C}$, its grains are surrounded by water. Considering ice grains as spherical inclusions in water, the Maxwell-Garnett dielectrics mixing formula is applicable [8]:

$$
\varepsilon_{\mathrm{wi}}=\left(\frac{\left(\varepsilon_{\mathrm{di}}+2 \varepsilon_{\mathrm{pw}}\right)+2\left(\varepsilon_{\mathrm{di}}-\varepsilon_{\mathrm{pw}}\right)\left(1-P_{\mathrm{w}}\right)}{\left(\varepsilon_{\mathrm{di}}+2 \varepsilon_{\mathrm{pw}}\right)-\left(\varepsilon_{\mathrm{di}}-\varepsilon_{\mathrm{pw}}\right)\left(1-P_{\mathrm{w}}\right)}\right) \varepsilon_{\mathrm{pw}},
$$

where $\varepsilon_{\mathrm{wi}}, \varepsilon_{\mathrm{di}}, \varepsilon_{\mathrm{pw}}-$ complex relative permittivity wet ice, dry ice, and clean water, respectively; $P_{\mathrm{w}}-$ volume fraction water $\left(\mathrm{m}^{3} / \mathrm{m}^{3}\right)$. Each part equation (10) is a function the real and imaginary parts the complex relative permittivity dry ice and the corresponding parts water.

Real and imaginary parts wet ice according to (10) at $f=20 \mathrm{GHz}$ and $T_{\mathrm{wi}}=0{ }^{\circ} \mathrm{C}$ (Fig. 3a) depending on the water content $P_{\mathrm{w}}$ and from $f$ (Fig. 3b) with a fraction the water content $P_{\mathrm{w}}=0,1 ; 0,2 ; 0,3$ shows a significant increase in indicators with an increase in the share water content. 


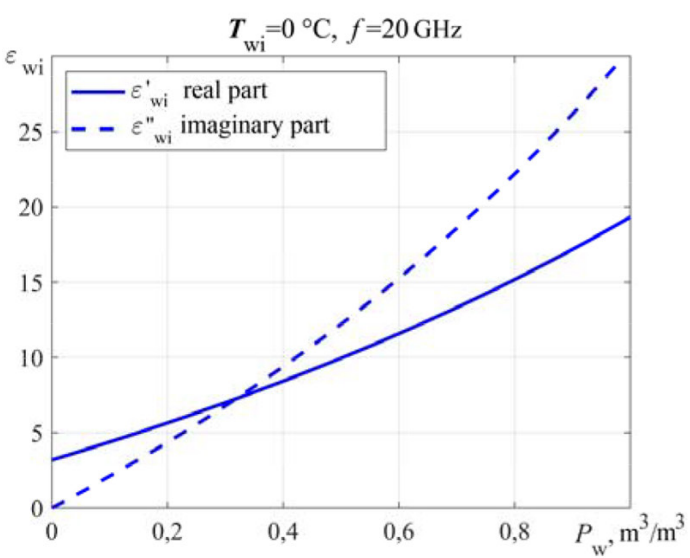

a)

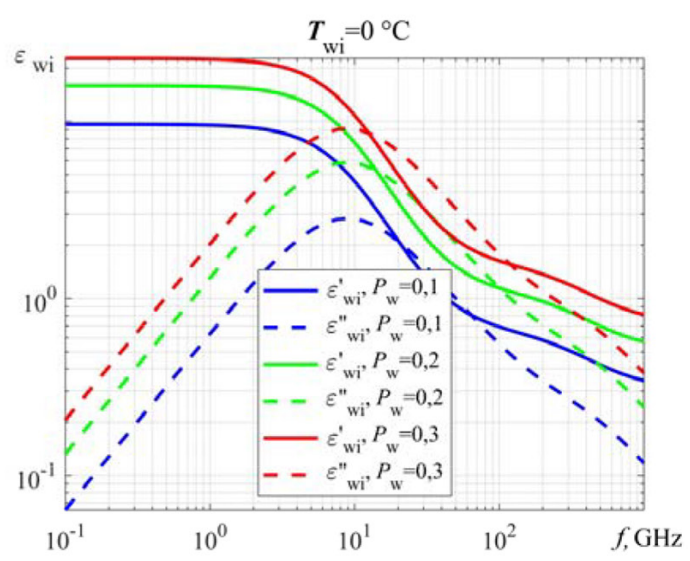

b)

Fig. 3. Dependence the complex relative permittivity wet ice $\varepsilon_{\mathrm{wi}}$ by (10) depending from: a - the proportion liquid water content $P_{\mathrm{w}}$ at $f=20 \mathrm{GHz} ; \mathrm{b}$ - the frequency $f$ with the proportion liquid water content $P_{\mathrm{w}}=0,1 ; 0,2 ; 0,3$ at $T_{\mathrm{wi}}=0{ }^{\circ} \mathrm{C}$

\section{The speed propagation an electromagnetic wave in the operating frequency range}

In General, the real subsurface structures medium is largely not uniform, so it is difficult to take into account their parameters when modeling without averaged values for subsequent studies. The structure the medium an unprepared site for landing on a snow-ice underlying surface, as a rule, consists of several layers, it can be snow, firn, ice, clean water and sea water.

The depth penetration EW $\delta_{\mathrm{d}}$ in work [8], defined as the depth at which the field strength amplitude within the medium falls to $1 / e$ (about $37 \%$ ) from its original value on the surface

$$
\delta_{\mathrm{d}}=\frac{\lambda}{2 \pi} \sqrt{\frac{2}{\sqrt{\varepsilon_{\mathrm{r}}^{\prime 2}+\varepsilon_{\mathrm{r}}^{\prime 2}}-\varepsilon_{\mathrm{r}}^{\prime}}},
$$

where $\lambda$ - the wavelength the probing signal; $\varepsilon_{\mathrm{r}}^{\prime}$ and $\varepsilon_{\mathrm{r}}^{\prime \prime}-$ the real and imaginary part the dielectric constant the medium, respectively. One the criteria for selecting the frequency range is the depth penetration (11) into the snow at frequencies $2 \ldots 8 \mathrm{GHz}$ about $10 \mathrm{~m}$ and a resolution about $4 \mathrm{~cm}$ in the ranges $C \ldots S(3,75 \ldots 15 \mathrm{~cm})$, this allows you to get a reflected signal from the interface between the medium «air-snow», «snow-ice», «ice-water».

The speed propagation EW in the medium $V_{\mathrm{r}}$ is:

$$
V_{\mathrm{r}}(f)=\frac{c}{\sqrt{\varepsilon_{\mathrm{r}}^{\prime}(f) \mu_{\mathrm{r}} \frac{1+\sqrt{1+\tan ^{2} \delta}}{2}}}
$$

where

$$
\tan \delta=\frac{\varepsilon_{\mathrm{r}}^{\prime \prime}(f)+\frac{\sigma_{\mathrm{dc}}}{2 \pi f \varepsilon_{0}}}{\varepsilon_{\mathrm{r}}^{\prime}(f)} ;
$$

$\mu_{\mathrm{r}}$-magnetic permeability the medium; tg $\delta$ - the tangent the dielectric loss angle; $\sigma_{\mathrm{dc}}-$ the final conductivity direct current losses in the dielectric; $\varepsilon_{0}=8,854187817 \times 10^{-12} \mathrm{~F} / \mathrm{m}$ - the permittivity the vacuum. 
Unlike materials with noticeable magnetic properties such as iron (ferrites), cobalt, nickel and their alloys, many materials are not magnetic, which makes their magnetic permeability very close to that vacuum $\mu_{\mathrm{r}} \approx 1$ (air, water, aluminum, copper), therefore, in such oil-absorbing dielectric medium as snow, firn and ice, the dielectric losses at frequencies of $2 \ldots 8 \mathrm{GHz}$ are small $[4,7]$, and the speed EW propagation in the medium $V_{\mathrm{r}}$ depends only on the relative permittivity $\varepsilon_{\mathrm{r}}^{\prime}$ medium. In frequency bands $f=2 \ldots 8 \mathrm{GHz}$ the imaginary part $\varepsilon^{\prime \prime}(f)$ small compared to the real part $\varepsilon^{\prime}(f)$ and do not show a relaxation of the permittivity. Under these conditions, the EW propagation rate is determined for nonsaline medium

$$
V_{\mathrm{r}}(f)=\frac{c}{\sqrt{\varepsilon_{\mathrm{r}}^{\prime}(f)}}
$$

Complex relative permittivity $\varepsilon_{\mathrm{pw}}$ pure water $S_{\mathrm{pw}}=0 \mathrm{~g} / \mathrm{kg}$ (Fig. $4 \mathrm{a}$ ), $\varepsilon_{\mathrm{sw}}$ sea water $S_{\mathrm{sw}}=35 \mathrm{~g} / \mathrm{kg}$ (Fig. $4 \mathrm{~b}$ ) and the speed propagation EW in pure water $V_{\mathrm{pw}} S_{\mathrm{pw}}=0 \mathrm{~g} / \mathrm{kg}$ (Fig. 5a), $V_{\mathrm{sw}}$ sea water

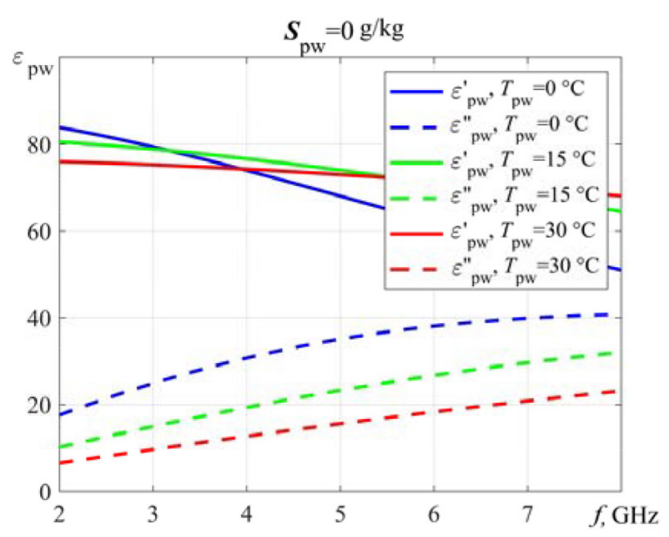

a)

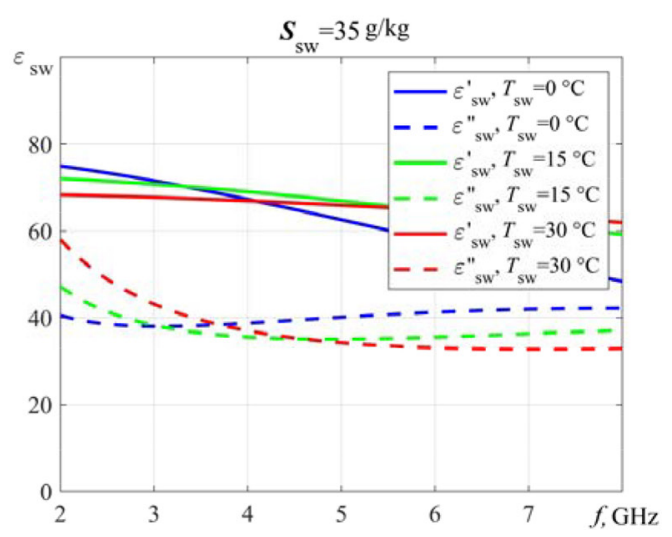

b)

Fig. 4. Dependence the complex relative permittivity: a $-\varepsilon_{\mathrm{pw}}$ pure water $S_{\mathrm{pw}}=0 \mathrm{~g} / \mathrm{kg}$ by (1-3); b $-\varepsilon_{\mathrm{sw}}$ sea water $S_{\mathrm{sw}}=35 \mathrm{~g} / \mathrm{kg}$ by (4-6) from frequency $f=2 \ldots 8 \mathrm{GHz}$ at $T_{\mathrm{r}}=0 ; 15 ; 30{ }^{\circ} \mathrm{C}$

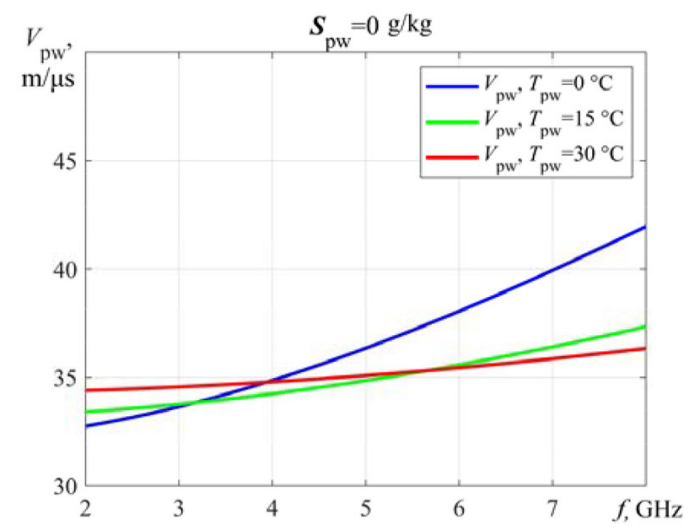

a)

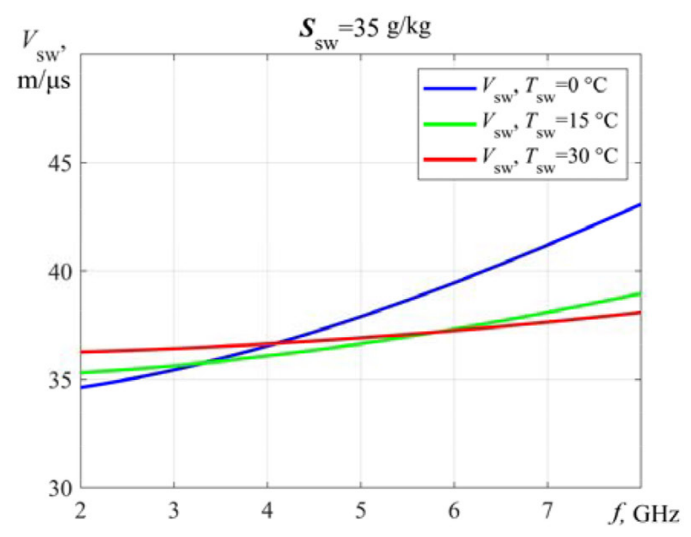

b)

Fig. 5. Dependence the EW propagation rate for: a $-V_{\mathrm{pw}}$ pure water $S_{\mathrm{pw}}=0 \mathrm{~g} / \mathrm{kg}$ by (2) and (13); b $-V_{\mathrm{sw}}$ sea water $S_{\mathrm{sw}}=35 \mathrm{~g} / \mathrm{kg}$ by (5) and (13) from frequency $f=2 \ldots 8 \mathrm{GHz}$ at $T_{\mathrm{r}}=0 ; 15 ; 30^{\circ} \mathrm{C}$ 
$S_{\mathrm{sw}}=35 \mathrm{~g} / \mathrm{kg}$ (Fig. $5 \mathrm{~b}$ ) in the operating frequency range $f=2 \ldots 8 \mathrm{GHz}$ it has a smoothly changing character.

With increasing temperature $T_{\mathrm{r}}=0 ; 15 ; 30^{\circ} \mathrm{C}$ and frequency $f$ the changes are more pronounced.

The real part the complex relative permittivity dry ice $\varepsilon_{\mathrm{di}}^{\prime}$ does not depend on frequency $f=2 \ldots 8 \mathrm{GHz}$ (Fig. 6a), but only from the temperature $T_{\mathrm{di}}=0 ;-10 ;-40{ }^{\circ} \mathrm{C}$ within a small range, which is also seen on the velocity propagation $\mathrm{EW} V_{\mathrm{di}}$ (Fig 6b).

Significant contribution to the complex relative permittivity wet ice $\varepsilon_{\mathrm{wi}}$ contributes a percentage water content $P_{\mathrm{w}}$ (Fig. 7). For the frequency $f=2 ; 8 \mathrm{GHz}$ by $T_{\mathrm{wi}}=0{ }^{\circ} \mathrm{C}$ there is a very strong growth both real and imaginary parts.

With increasing frequency $f=2 \ldots 8 \mathrm{GHz}$ there is a decrease in the actual part the complex relative permittivity wet ice $\varepsilon_{\mathrm{wi}}^{\prime}$ (Fid. 8a) and accordingly the increase in the speed EW propagation in wet ice $V_{\text {wi }}$ (Fig. 8b), with a fraction the water content $P_{\mathrm{w}}=0,01 ; 0,1 ; 0,2$.

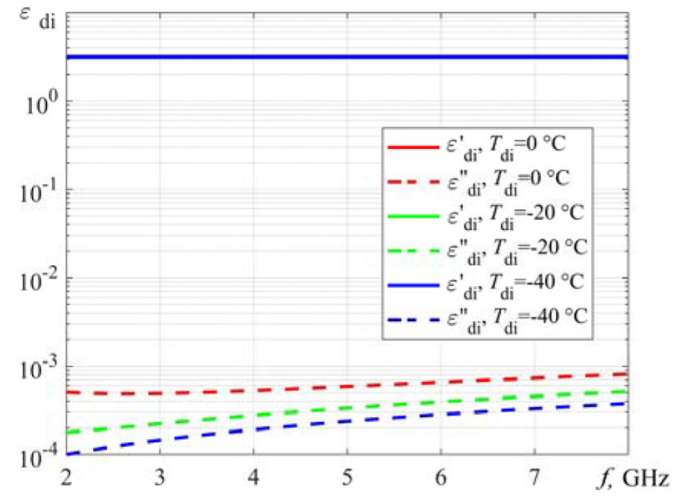

a)

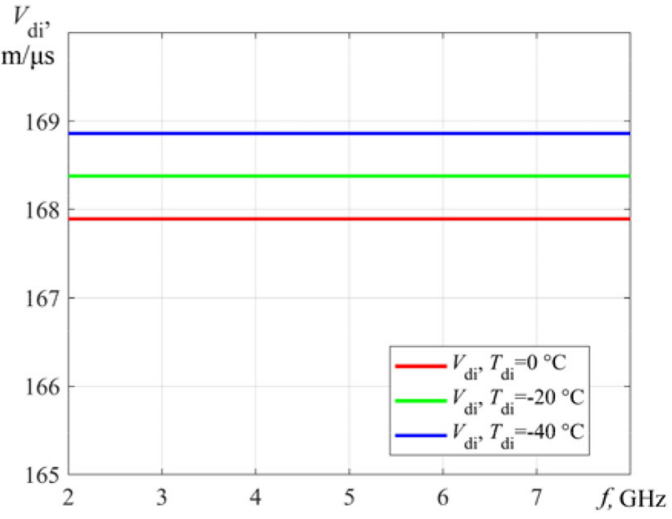

b)

Fig. 6. Dependence: a - the complex relative permittivity dry ice $\varepsilon_{\mathrm{di}}$ by (7-9); b - propagation rate the EW $V_{\mathrm{di}}$ by (8) and (13) from frequency $f=2 \ldots 8 \mathrm{GHz}$ at $T_{\mathrm{di}}=0 ;-10 ;-40{ }^{\circ} \mathrm{C}$

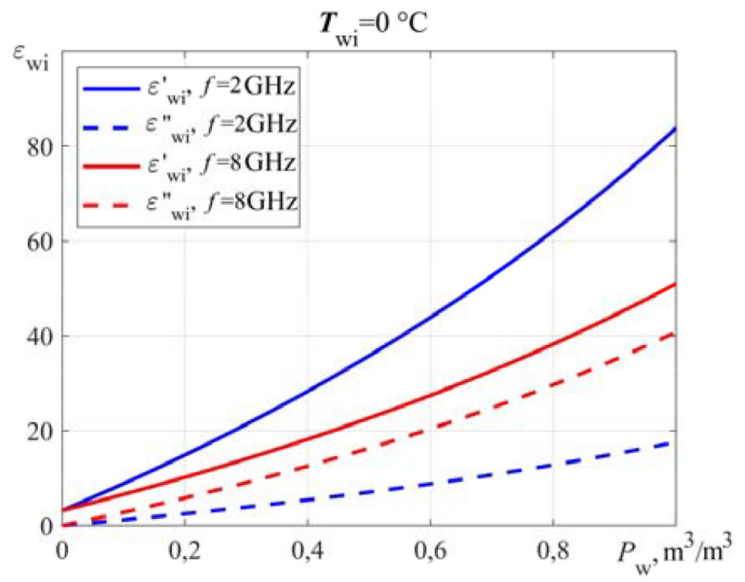

Fig. 7. Dependence the complex relative permittivity wet ice $\varepsilon_{\mathrm{wi}}$ by (10) from the proportion of content liquid water $P_{\mathrm{w}}$ for the $f=2 ; 8 \mathrm{GHz}$ at $T_{\mathrm{wi}}=0{ }^{\circ} \mathrm{C}$ 


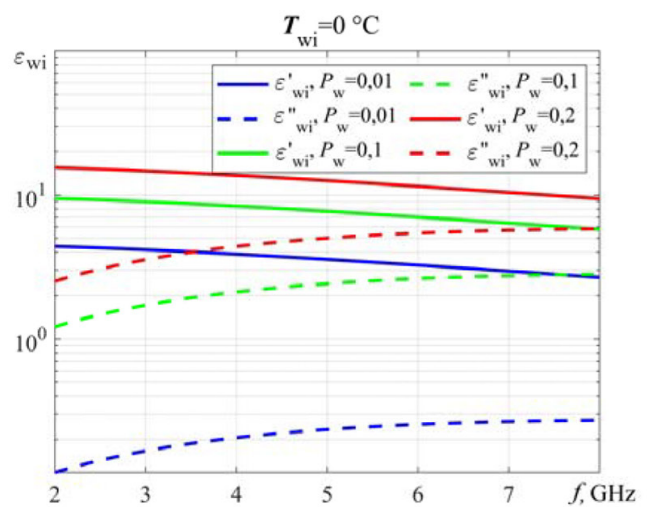

a)

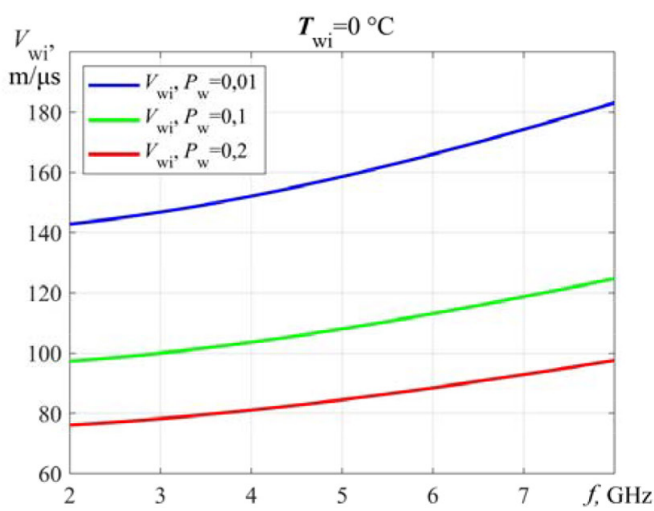

b)

Fig. 8. Dependence: a - the complex relative permittivity wet ice $\varepsilon_{\mathrm{wi}}$ by $(10) ; \mathrm{b}$ - propagation rate the EW in the wet ice $V_{\mathrm{wi}}$ by (10) and (13), with the proportion of the liquid water content $P_{\mathrm{w}}=0,01 ; 0,1 ; 0,2$ from the frequency $f=2 \ldots 8 \mathrm{GHz}$ at $T_{\mathrm{wi}}=0{ }^{\circ} \mathrm{C}$

Snow cover both on land and on glaciers, depending on the conditions formation and occurrence, is in a dry or wet state, it consists layers and layers snow and ice different densities, water content and structures formed as a result snowfalls, thaws and cold spells.

Depending on the proportion water content, the snow cover is a two-phase (dry) or three-phase (wet) system consisting ice crystals, water and air containing water vapor.

To describe the relative permittivity snow $\varepsilon_{\mathrm{s}}^{\prime}$ as a mixture two dielectrics ice and air with relative permittivity $\varepsilon_{\mathrm{i}}^{\prime}$ and $\varepsilon_{\mathrm{a}}^{\prime}$ or ice and water with relative permittivity $\varepsilon_{\mathrm{i}}^{\prime}$ and $\varepsilon_{\mathrm{w}}^{\prime}$ as a function their volume concentration a number equations are proposed in the works [2, 14-18].

In the first approximation, the dependence the dielectric constant the medium $\varepsilon_{\mathrm{r}}^{\prime}\left(\operatorname{dry}\right.$ snow $\varepsilon_{\mathrm{ds}}^{\prime}$, firn $\varepsilon_{\mathrm{df}}^{\prime}$, ice's $\left.\varepsilon_{\mathrm{di}}^{\prime}\right)$ from density $\rho_{\mathrm{r}}\left(\rho_{\mathrm{ds}}, \rho_{\mathrm{df}}, \rho_{\mathrm{di}}\right)$ and volume content the medium $v_{\mathrm{r}}\left(v_{\mathrm{ds}}, v_{\mathrm{df}}, v_{\mathrm{di}}\right)$ can be described by K. Lichtenecker's formula [2, 20]:

$$
\lg \varepsilon_{\mathrm{r}}^{\prime}=v_{\mathrm{r}} \lg \varepsilon_{\mathrm{i}}^{\prime}\left(1-v_{\mathrm{r}}\right) \lg \varepsilon_{\mathrm{a}(\mathrm{w})}^{\prime},
$$

where $v_{\mathrm{r}}=\rho_{\mathrm{r}} / \rho_{\mathrm{i}}-$ volume content medium; $\rho_{\mathrm{i}}=917 \mathrm{~kg} / \mathrm{m}^{3}$ - the density dry ice without air inclusions.

Lueng's formula $[2,21,22]$ for such medium with spherical air and ice inclusions:

$$
\dot{\varepsilon}_{\mathrm{r}}^{\prime}=\left(v_{\mathrm{i}}\left(\sqrt[3]{\varepsilon_{\mathrm{i}}^{\prime}}-1\right)+1\right)^{3}
$$

where $v_{\mathrm{i}}=\rho_{\mathrm{r}} / \rho_{\mathrm{i}}-$ volume content ice; $\rho_{\mathrm{r}}-$ density the dry medium (dry snow $\rho_{\mathrm{ds}}$, firn's $\rho_{\mathrm{df}}$, ice's $\left.\rho_{\mathrm{di}}\right)$.

According to the empirical formula of G. Robin [2, 21], the dielectric constant of the medium is determined by

$$
\varepsilon_{\mathrm{r}}^{\prime}=\left(1+8,845 \rho_{\mathrm{r}}\right)^{4} .
$$

Close ratio $[2,24]$

$$
\varepsilon_{\mathrm{r}}^{\prime}=\left(1+0,848 \rho_{\mathrm{r}}\right)^{2}
$$


obtained from the analysis radar logging a borehole on the Island Devon (Canadian Arctic Archipelago) and in the analysis of radiosonde data on the McMurdo ice shelf (Antarctica) and available laboratory and field measurement materials $[2,25]$

$$
\varepsilon_{\mathrm{r}}^{\prime}=\left(1+0,845 \rho_{\mathrm{r}}\right)^{2}
$$

Experimental dependencies obtained by different authors $\varepsilon_{\mathrm{r}}^{\prime}\left(\varepsilon_{\mathrm{ds}}^{\prime}, \varepsilon_{\mathrm{df}}^{\prime}, \varepsilon_{\mathrm{di}}^{\prime}\right)$ from density $\rho_{\mathrm{r}}\left(\rho_{\mathrm{ds}}\right.$, $\left.\rho_{\mathrm{df}}, \rho_{\mathrm{di}}\right)$, they show a very close agreement with the calculations based on the G. Lueng formula (15), while the maximum discrepancy with the results calculations based on empirical and computational dependencies does not exceed $2 \ldots 3 \%$ by $\varepsilon_{\mathrm{r}}^{\prime}\left(\varepsilon_{\mathrm{ds}}^{\prime}, \varepsilon_{\mathrm{df}}^{\prime}, \varepsilon_{\mathrm{di}}^{\prime}\right)$ at a density more than $400 \mathrm{~kg} / \mathrm{m}^{3}$ [2]. The real part the complex relative permittivity the medium $\varepsilon_{\mathrm{r}}^{\prime}$ (snow, firn, ice) and the speed EW propagation in the medium $V_{\mathrm{r}}$ with density $\rho_{\mathrm{r}}-100 ; 500 ; 700 ; 917 \mathrm{~kg} / \mathrm{m}^{3}$ according to (15) do not depend on $f=2 \ldots 8 \mathrm{GHz}$, but only from $T$ within small limits as for dry ice (Fig. 6). Relative permittivity a wet medium $\varepsilon_{\mathrm{vr}}^{\prime}$ (wet snow $\varepsilon_{\mathrm{ws}}^{\prime}$, firn's $\varepsilon_{\mathrm{wf}}^{\prime}$, ice's $\varepsilon_{\mathrm{wi}}^{\prime}$ ) depending on the percentage water content $P_{\mathrm{w}}$ it is also described by the Lueng formula $[2,22]$. For a two-component ice-water mixture with water-filled pores

$$
\varepsilon_{\mathrm{vr}}^{\prime}=\left(\sqrt[3]{\varepsilon_{\mathrm{r}}^{\prime}}+P_{\mathrm{w}}\left(\sqrt[3]{\varepsilon_{\mathrm{w}}^{\prime}}-\sqrt[3]{\varepsilon_{\mathrm{i}}^{\prime}}\right)\right)^{3}
$$

where $\varepsilon_{\mathrm{i}}^{\prime}$ and $\varepsilon_{\mathrm{W}}^{\prime}$ relative permittivity ice and water, respectively.

For a three-component medium consisting ice with water and air inclusions, given (22) we obtain $[2,26]$

$$
\varepsilon_{\mathrm{vr}}^{\prime}=\left(\sqrt[3]{\varepsilon_{\mathrm{r}}^{\prime}}\left(1-P_{\mathrm{wa}}\right)+P_{\mathrm{w}}\left(\sqrt[3]{\varepsilon_{\mathrm{w}}^{\prime}}+P_{\mathrm{wa}}-P_{\mathrm{w}}\right)\right)^{3}
$$

where $P_{\text {wa }}-$ the total percentage water and air content («total» porosity warm ice).

Relationship between the relative permittivity a dry medium $\varepsilon_{\mathrm{r}}^{\prime}$ and humid medium $\varepsilon_{\mathrm{vr}}^{\prime}$ can be described by formulas [2, 24]:

$$
\begin{aligned}
& \varepsilon_{\mathrm{r}}^{\prime}=\left(1+1,7 \rho_{\mathrm{r}}+0,80 \rho_{\mathrm{r}}^{2}\right) ; \\
& \varepsilon_{\mathrm{vr}}^{\prime}=\left(0,1 P_{\mathrm{w}}+0,80 P_{\mathrm{w}}^{2}\right) \varepsilon_{\mathrm{w}}^{\prime}+\varepsilon_{\mathrm{r}}^{\prime} ; \\
& \varepsilon_{\mathrm{vr}}^{\prime \prime}=\left(0,1 P_{\mathrm{w}}+0,80 P_{\mathrm{w}}^{2}\right) \varepsilon_{\mathrm{w}}^{\prime \prime},
\end{aligned}
$$

where $\varepsilon_{\mathrm{vr}}^{\prime \prime}$ and $\varepsilon_{\mathrm{w}}^{\prime \prime}$ - factors wet environment and water loss, respectively.

With an increase in the proportion water content in the medium $P_{\mathrm{w}}$ (Fig. 9a) there is a drop in the speed EW propagation in the medium $V_{\mathrm{r}}$ (snow, firn, ice) with completely filled pores with water calculated by (19) and the density the medium $\rho_{\mathrm{r}}$ (Fig. 9b), there is also a drop in the rate EW propagation in the medium $V_{\mathrm{r}}$ with a total share water and air $P_{\mathrm{wa}}-0,1 ; 0,3 ; 0,5 ; 0,6$ and water $P_{\mathrm{w}}-0$; 0,$1 ; 0,2 ; 0,3$ according to (20) for $f=8 \mathrm{GHz}$ by $T_{\mathrm{r}}=0{ }^{\circ} \mathrm{C}$, a with an increase in the proportion air content $P_{\text {a }}$ speed increases.

The speed of propagation EW in the medium $V_{\mathrm{r}}$ (right scale) depending on the percentage water content $P_{\mathrm{w}}=0 \ldots 0,1$ (lower scale) and medium density (snow, firn, ice) $\rho_{\mathrm{r}}$ (left-hand scale) at $T_{\mathrm{r}}=0{ }^{\circ} \mathrm{C}$ for the frequency $f=2 \mathrm{GHz}$ (Fig. 10a) and $f=8 \mathrm{GHz}$ (Fig. 10b) shows an increase in speeds on compared to in looser structures and a drop in denser structures. 


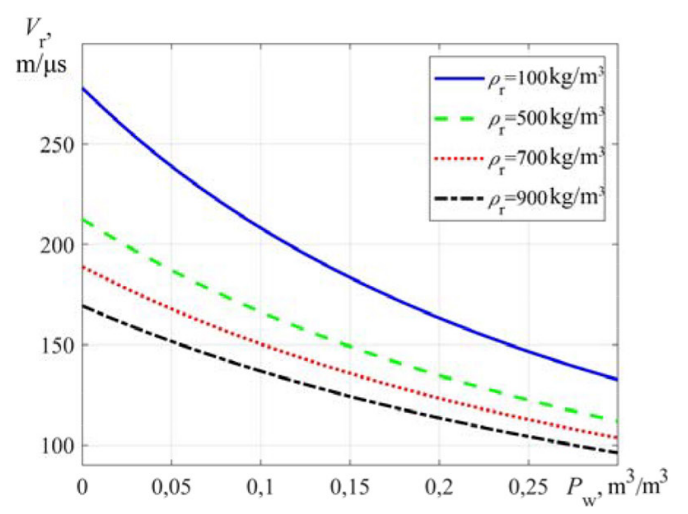

a)

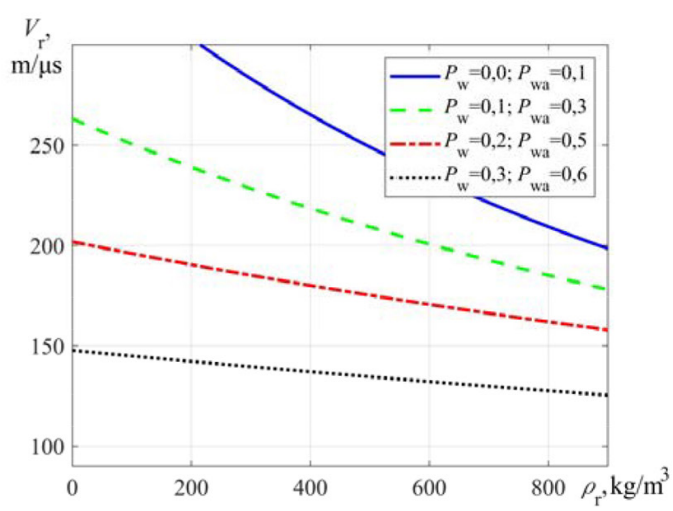

b)

Fig. 9. Dependence propagation rate the EW by $V_{\mathrm{r}}$ (snow, firn, ice) from a - percentage of liquid water content $P_{\mathrm{w}}$ for medium density $\rho_{\mathrm{r}}-100 ; 500 ; 700 ; 900 \mathrm{~kg} / \mathrm{m}^{3}$ with fully filled pores with water by $(19) ; \mathrm{b}-$ density of medium $\rho_{\mathrm{r}}$ with a total proportion of liquid water and air $P_{\mathrm{wa}}-0,1 ; 0,3 ; 0,5 ; 0,6$ and liquid water $P_{\mathrm{w}}-0 ; 0,1 ; 0,2 ; 0,3$ by (20) for $f=8 \mathrm{GHz}$ at $T_{\mathrm{r}}=0{ }^{\circ} \mathrm{C}$

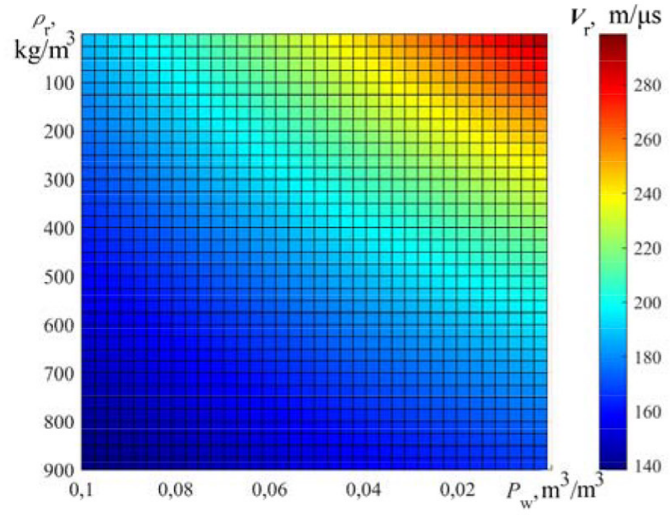

a)

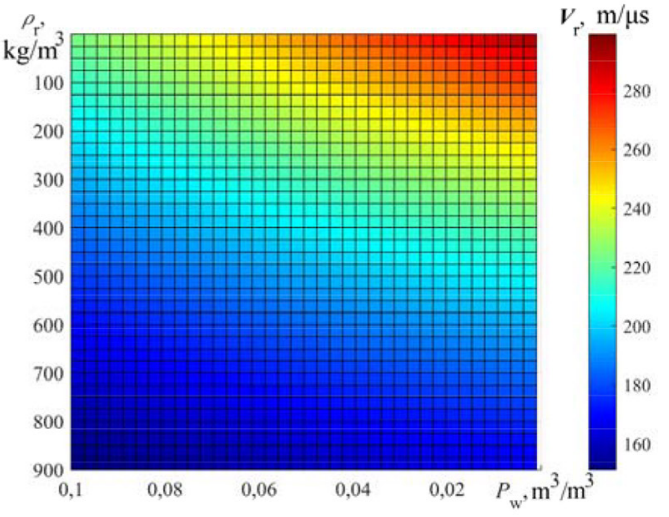

b)

Fig. 10. Dependence propagation rate the EW by (snow, firn, ice) (13) $V_{\mathrm{r}}$ (snow, firn, ice) from the density of the medium (21) $\rho_{\mathrm{r}}$ and the percentage of liquid water content (22) $P_{\mathrm{w}}=0 \ldots 0,1$ for: $\mathrm{a}-f=2 \mathrm{GHz} ; \mathrm{b}-f=8 \mathrm{GHz}$ at $T_{\mathrm{r}}=0{ }^{\circ} \mathrm{C}$

How can it be seen that for dry medium, the EW propagation velocity at $T_{\mathrm{r}}=0{ }^{\circ} \mathrm{C}$ are in the intervals: for dry snow $-V_{\mathrm{ds}}=278,1 \ldots 212,7 \mathrm{~m} / \mu \mathrm{s}$; for dry firn $-V_{\mathrm{df}}=212,7 \ldots 189,0 \mathrm{~m} / \mu \mathrm{s}$; for dry ice $V_{\mathrm{di}}=189,0 \ldots 167,9 \mathrm{~m} / \mu \mathrm{s}$. The picture is changing with the increase in the proportion water content $P_{\mathrm{w}}$, because for pure water $V_{\mathrm{pw}}=32,74 \ldots 41,97 \mathrm{~m} / \mu \mathrm{s}$.

An important factor affecting the speed EW propagation is the shape, size, and orientation air and water inclusions in dry and wet snow, firn, and ice. In [28] it is shown that when water inclusions are perpendicular to the EW direction, they have high velocities in the ice, and lower velocities when they are parallel to the EW direction, i.e. if the inclusions are drawn parallel and normal to the ice surface the snow-ice cover.

For medium with disc-shaped inclusions, the dielectric constant in the parallel direction $\varepsilon_{\mid}$and perpendicular $\varepsilon_{\perp} \mathrm{EF}$, described by the ratio [2, 28]: 


$$
\begin{gathered}
\varepsilon_{\|}=\frac{\left(1-A_{\mathrm{d}}\right) \varepsilon_{\mathrm{i}} \varepsilon_{\mathrm{w}}+\left(A_{\mathrm{d}}+2\right)\left(\varepsilon_{\mathrm{i}} \varepsilon_{\mathrm{w}}+P_{\mathrm{w}} \varepsilon_{\mathrm{w}}^{2}-P_{\mathrm{w}} \varepsilon_{\mathrm{i}} \varepsilon_{\mathrm{w}}\right)}{\left(1-A_{\mathrm{d}}\right) \varepsilon_{\mathrm{w}}\left(1-P_{\mathrm{w}}\right)+\left(2+A_{\mathrm{d}}\right) \varepsilon_{\mathrm{w}}} ; \\
\varepsilon_{\perp}=\frac{\left(1+2 A_{\mathrm{d}}\right) \varepsilon_{\mathrm{i}} \varepsilon_{\mathrm{w}}+\left(2-2 A_{\mathrm{d}}\right)\left(\varepsilon_{\mathrm{i}} \varepsilon_{\mathrm{w}}+\varepsilon_{\mathrm{w}}^{2}-P_{\mathrm{w}} \varepsilon_{\mathrm{w}}^{2}\right)}{\left(1+2 A_{\mathrm{d}}\right)+\varepsilon_{\mathrm{w}}\left(1-P_{\mathrm{w}}\right)+\left(2-2 A_{\mathrm{d}}\right) \varepsilon_{\mathrm{w}}}
\end{gathered}
$$

where $\varepsilon_{\mathrm{i}}$ and $\varepsilon_{\mathrm{w}}$ the permittivity the host ice and water inclusions, respectively; $P_{\mathrm{w}}$ - volume fraction water content; $A_{\mathrm{d}}$ - depolarization factor that characterizes how ordered the orientation inclusions is (stretched in one direction $-A_{\mathrm{d}}=1$, randomly placed $-A_{\mathrm{d}}=0$ ).

The calculations performed by Kotlyakov V.M., Macheret Yu.Ya., Sosnovsky A.V., Glazovsky A.F. in [2] indicate the applicability the Lueng formula (19) for estimating the average density dry snow cover and show that the speed EW propagation in snow, firn, and ice depends on the density $\rho_{\mathrm{r}}$, the proportion water content $P_{\mathrm{w}}$, the structure can change over a wide range. So in dry snow cover, with an average density of $\rho_{\mathrm{ds}}=400 \ldots 500 \mathrm{~kg} / \mathrm{m}^{3}$, the average speed is close to the EW $V_{\mathrm{ds}}=190 \mathrm{~m} / \mu \mathrm{s}$. However, it will change greatly depending on the preferred orientation and shape ice and air inclusions in the snow. In dry snow with vertically and horizontally elongated and spherical inclusions the speeds differ by $38 \mathrm{~m} / \mu \mathrm{s}(16 \%)$ at a snow density of $300 \mathrm{~kg} / \mathrm{m}^{3}$ and at $15 \mathrm{~m} / \mu \mathrm{s}(7 \%)$ at a density of $500 \mathrm{~kg} / \mathrm{m}^{3}$ and the ratio semi-axes ellipsoids $p=2$. By $p=4$ this difference is $61 \mathrm{~m} / \mu \mathrm{s}$ $(26 \%)$ and $23 \mathrm{~m} / \mu \mathrm{s}(11 \%)$ respectively.

\section{Conclusion}

Thus, if it is possible to remotely measure the speed EW propagation in medium $V_{\mathrm{r}}$, the average density medium $\rho_{\text {raver }}$ can be estimated, as well as the average water content in medium $P_{\mathrm{w} \text { aver, }}$ which will allow remote identification the medium (underlying surface), more accurately determine the depth snow and the thickness the ice cover, in order to perform a safe landing a helicopter-type aircraft on an unprepared area with snow and ice cover.

When the proportion water content in the medium $P_{\mathrm{w}}=0$, for the temperature the medium $T_{\mathrm{r}}<0{ }^{\circ} \mathrm{C}$, which is typical, for example, for the Arctic territories, the task identifying the medium (underlying surface) is simplified, since the speed EW propagation in the medium $V_{\mathrm{r}}$ will depend only on the density $\rho_{\mathrm{r}}$ and the structure these medium.

Knowing the intervals electromagnetic wave propagation speeds $V_{\mathrm{ds}}=278,1 \ldots 212,7 \mathrm{~m} / \mu \mathrm{s}$ for dry snow, $V_{\mathrm{df}}=212,7 \ldots 189,0 \mathrm{~m} / \mu \mathrm{s}$ for dry firn and $V_{\mathrm{di}}=189,0 \ldots 167,9 \mathrm{~m} / \mu \mathrm{s}$ for dry ice, allows you to remotely identify the medium and more accurately determine the depth snow and the thickness the ice cover to assess the possibility landing a helicopter-type aircraft on an unprepared area with snow and ice cover.

\section{References}

[1] Машков В.Г., Малышев В.А. Способ выбора площадки для посадки воздушного судна вертолетного типа. Пат. 2707275 Российская Федерация, МПК G01S 13/94; заявитель и патентообладатель ВУНЦ ВВС «ВВА» (г. Воронеж) 2019100117; заявл. 09.01.2019; опубл. 26.11.2019 [Mashkov V.G., Malyshev V.A. Method selecting a landing site for a helicopter - type aircraft. Pat. 2707275 Russian Federation, IPC G01S 13/94; applicant and patent holder VUNTS VVS «VVA» (Voronezh) 2019100117; declared 09.01.2019; publ. 26.11.2019 (in Russian)]

[2] Котляков В.М., Мачерет Ю.Я., Сосновский А.В., Глазовский А.Ф. Скорость распространения радиоволн в сухом и влажном снежном покрове. Лед и снег. М.: Институт 
географии РАН, 2017, 57(1), 45-56 [Kotlyakov V.M., Macheret Yu.Ya., Sosnovsky A.V., Glazovsky A.F. Speed radio wave propagation in dry and wet snow cover. Ice and snow. Moscow, Institute geography the Russian Academy of Sciences, 2017, 57(1), 45-56 (in Russian)]

[3] Dowdeswell J.A., Evans S. Investigations of the form and flow of ice sheets and glaciers using radio-echo sounding. Reports on Progress in Physics, 2004, 67, 1821-1861

[4] Мачерет Ю.Я. Радиозондирование ледников. М.: Научный мир, 2006, 392 с. [Macheret Yu. Ya. Sounding of glaciers. Moscow, Scientific world, 2006, 392 p. (in Russian)]

[5] Глазовский А.Ф., Мачерет Ю.Я. Вода в ледниках. Методы и результаты геофизических и дистанционных исследований. М.: ГЕОС, 2014, 528 с. [Glazovsky A.F., Macheret Yu.Ya. Water in glaciers. Methods and results of geophysical and remote research. Moscow, GEOS, 2014, 528 p. (in Russian)]

[6] Беховых Л.А., Макарычев С.В., Шорина И.В. Основыгидрофизики. Барнаул: Издательство АГАУ, 2008, 172 c. [Begovich L.A., Makarychev S.V., Shorina I.V. Fundamentals hydrophysics. Barnaul, Publishing house of the Altai state agrarian University, 2008, 172 p. (in Russian)]

[7] Основы измерения диэлектрических свойств материалов. Заметки по применению. М.: Российское представительство Agilent Technologies, 2010, 32 с. [Fundamentals measuring the dielectric properties materials. Notes on the application. M., Russian representative office Agilent Technologies, 2010, 32 p. (in Russian)]

[8] Рекомендаиия MCЭ-R P.527-4. Электрические характеристики земной поверхности. Серия Р. Распространение радиоволн. М.: Международный союз электросвязи, 2017, 19 с. [Recommendation ITU-R P. 527-4. Electrical characteristics the earth's surface. Series R. radio wave Propagation. Moscow, international telecommunication Union, 2017, 19 p. (in Russian)]

[9] Мосин О.В. Диэлектрические свойства воды и льда [Электронный ресурс] - Режим доступа: http://www.o8ode.ru/article/krie/Dielectric_properties_of_water_and_ice - Заглавие c экрана. [Mosin O.V. Dielectric properties of water and ice [Electronic resource] - Access: http://www. o8ode.ru/article/krie/Dielectric_properties_of_water_and_ice (in Russian)]

[10] Плотность воды, теплопроводность и физические свойства $\mathrm{H}_{2} \mathrm{O}$ [Электронный pecypc] - Режим доступа: http://thermalinfo.ru/svojstva-zhidkostej/voda-i-rastvory/ teploprovodnost -i-plotnost-vody-teplofizicheskie-svojstva-vody-h2o - Заглавие с экрана. [Water density, thermal conductivity and physical properties of $\mathrm{H} 2 \mathrm{O}$ [Electronic resource] - Access: http://thermalinfo.ru/svojstva-zhidkostej/voda-i-rastvory/teploprovodnost-i-plotnost-vody-teplofizi cheskie- svojstva-vody-h2o (in Russian)]

[11] Арабаджи В.С. Электризация снега в метелях. Загадки простой воды. [Электронный pecypc] - Режим доступа: http:/class-fizika.narod.ru/w23.htm - Заглавие с экрана. [Arabadji V.S. The Electrification of snow in the blizzards. Riddles of simple water. [Electronic resource] - Access: http://class-fizika.narod.ru/w23.htm (in Russian)]

[12] Фролов А.Д., Мачерет Ю.Я. Оценка содержания воды в субполярных и теплых ледниках по данным измерений скорости распространения радиоволн. МГИ, 1998, 84, 148-154 [Frolov A.D., Macheret Yu.Ya. Assessment water content in Subpolar and warm glaciers according to measurements the speed radio wave propagation. MGI, 1998, 84, 148-154 (in Russian)]

[13] Frolov A.D., Macheret Yu.Ya. On dielectric properties of dry and wet snow. Hydrological processes, 1999, 13, 1755-1760.

$$
-345-
$$


[14] Denoth A. On the calculation of the dielectric constant of snow. Rencontre internationale sur la neige et les avalanches. Association nationale pour l'etude de la neige et des avalanches, 1978, 61-70.

[15] Denoth A. Effect of grain geometry on electrical properties of snow at frequencies up to 100 MHz. Journ. of Applied Physics, 1982, 53, 1(11), 7496-7501.

[16] Denoth A. Snow dielectric measurements. Advance Space Research, 1989, 9(1), 233-243.

[17] Denoth A., Schittelkopf H. Mixing formulas for deter mining the free water content of wet snow from mea surements of the dielectric constant. Zeitschrift fur letscherkunde und Glazialgeologie, 1978, 14(1), 73-80.

[18] Matzler C. Microwave permittivity of dry snow. IEEE Transactions on Geoscience and Remote Sensing, 1996, 34(2), 573-581.

[19] Stiles W.H., Ulaby F.T. Dielectric properties of snow. Proc. of the Workshop on the Properties of Snow, Snowbird, Utah, April 8-10, 1981. U.S. Army Cold Regions Research and Engineering Laboratory. Special report. № 82-18. United States, 91-103.

[20] Богородицкий В.В., Пасынков В.П. Материаль в радиоэлектронике. М.-Л.: Мосэнергоиздат, 1961, 352 с. [Bogoroditsky V.V., Pasynkov V.P. Materials in Radioelectronics. M.L., Gosenergoizdat, 1961, 352 p. (in Russian)]

[21] Looyenga H. Dielectric constants of heterogeneous mixture. Physica, 1965, 31(3), 401-406.

[22] Мачерет Ю.Я. Оценка содержания воды в ледниках по гиперболическим отражениям. Материаль гляииологических исследований. Институт географии РАН, 2000, 89, 3-10 [Macheret Yu.Ya. Assessment water content in glaciers by hyperbolic reflections. Materials glaciological research. Institute geography the Russian Academy Sciences, 2000, 89, 3-10 (in Russian)]

[23] Robin G. de Q. Velocity radio waves in ice by means interferometric technique. Journ. Glaciology, 1975, 15(73), 151-159.

[24] Tiuri M., Sihvola A., Nyfors E., Hillikainen M. The complex dielectric constant of snow using microwave techniques. IEEE Journ. of Oceanic Engineering, 1984, OE-9(5), 377-382.

[25] Kovacs A., Gow A., Morey R.M. A reassessment the in-situ dielectric constant polar firn. CREEL Report 93-26, 1993, 1-29.

[26] Macheret Yu.Ya. Estimation of absolute water content in Spitsbergen glaciers. Polar Research, 2000, 19(2), 205-216.

[27] Bradford J.H., Nichols J., Mikesell D., Harper J. Continuous profiles of electromagnetic velocity and water content in glaciers: an example from Bench glacier, Alaska, USA. Annals Glaciology, 2009, 50(51), 1-9.

[28] Giordano S. Order and disorder heterogeneous material microstructure: electric and elastic characterization dispersions pseudo-oriented spheroids. Intern. Journ. Engineering Science, 2005, 43, 1033-1058.

[29] Bradford J.H., Nichols J., Harper J.T., Meirbachtol T. Compressional and EM velocity anisotropy in a temperate glacier due to basal crevasses, and implications for water content estimation. Annals of Glaciology, 2013, 54(64), 168-178. 